\title{
KEBUTUHAN PROTEIN UNTUK PERTUMBUHAN YUWANA KEPITING BAKAU, Scylla paramamosain
}

\author{
Nyoman Adiasmara Giri, Yunus, Ketut Suwirya, dan Muhammad Marzuqi
}

\begin{abstract}
ABSTRAK
Budi daya kepiting belum berkembang baik terutama karena terbatasnya benih serta belum tersedianya pakan buatan. Penelitian ini bertujuan untuk mengetahui kebutuhan protein pakan bagi pertumbuhan yuwana kepiting bakau (Scylla paramamosain) sebagai data dasar untuk mengembangkan pakan buatan. Sebanyak 90 ekor yuwana kepiting bakau dipelihara pada 18 buah bak volume $30 \mathrm{~L}$. Setiap bak diisi 5 ekor kepiting yang dipisahkan secara individu dalam kurungan supernet. Kepiting diberi pakan 2 kali sehari berupa pelet kering dengan kandungan protein berbeda sesuai perlakuan, yaitu $25 \%, 30 \%, 35 \%, 40 \%, 45 \%$, dan $50 \%$ selama 6 minggu. Pakan dibuat isokalori dengan penambahan dekstrin. Hasil percobaan menunjukkan bahwa kandungan protein pakan berpengaruh nyata $(P<0,05)$ terhadap bobot akhir, pertambahan bobot, lebar karapas, efisiensi pakan, kandungan protein, dan lemak tubuh yuwana kepiting bakau, namun tidak berpengaruh nyata terhadap sintasannya. Peningkatan kandungan protein pakan juga meningkatkan kandungan protein tubuh ikan, dan sebaliknya menurunkan kandungan lemaknya. Kandungan protein pakan $45 \%$ menghasilkan pertumbuhan tertinggi dengan bobot akhir dan pertambahan bobot mencapai $7,05 \mathrm{~g}$ dan $1.942,6 \%$. Berdasarkan broken line analysis terhadap data persen pertambahan bobot diperoleh kesimpulan bahwa kebutuhan protein optimum untuk menghasilkan pertumbuhan maksimum yuwana kepiting bakau adalah $47,6 \%$.
\end{abstract}

ABSTRACT: Dietary protein requirement for growth of juvenile mud crab, Scylla paramamosain. By: Nyoman Adiasmara Giri, Yunus, Ketut Suwirya, and Muhammad Marzuqi

Mud crab culture has not been well developed yet due to unavailable seed supply and unavailable good artificial feed. The present study aimed to know the diefary protein requirement for growth of juvenile mud crab Scylla paramamosain as a basic data for developing its antificial feed. The experiment was conducted using 18 polycarbonate tanks, of $30 \mathrm{~L}$ volume each and equipped with flow-through water system. Five crablets from hatchery with initial weight of $0.35 \pm$ $0.08 \mathrm{~g}$ and carapace length of $1.36 \pm 0.09 \mathrm{~cm}$ were stocked individually using supernet in each tank. The crab were fed twice a day with experimental diet containing different levels of dietary protein, i.e. $25 \%, 30 \%, 35 \%, 40 \%, 45 \%$, and $50 \%$ for 6 weeks. Feeds were prepared as dry pellet and had the same energy content. Results of the experiment showed dietary protein contents significantly $(P<0.05)$ affected final weight, weight gain, carapace length, feed efficiency ( $F E)$, and protein and lipid content of juvenile mud crab. The survivals of crab all treatments were not significantly different $(P>0.05)$. Protein contents of the juvenile mud crab increased with increasing dietary protein levels. The highest final weight $(7.05 \mathrm{~g})$ and weight gain $(1,942.6 \%)$ were found on crab fed with $45 \%$ dietary protein diet. Broken line analysis on weight gain data showed that optimum dietary protein requirement for maximum growth of juvenile mud crab Scylla paramamosain was $47.6 \%$.

\section{KEYWORDS: Scylla paramamosain, protein requirement, growth}

\section{PENDAHULUAN}

Kepiting bakau merupakan salah satu komoditas perikanan Indonesia sejak awal tahun 1980. Total produksi kepiting Indonesia pada tahun 1997 mencapai 13.174 ton. Dari produksi ini $61,6 \%$ berasal dari penangkapan dan sisanya $38,4 \%$ merupakan hasil budi daya (Direktorat Jenderal Perikanan, 1999). Kendala utama dalam pengembangan budi daya kepiting bakau adalah ketersediaan benih yang terbatas karena benih belum dapat diproduksi secara terkontrol di hatcheri. Kendala berikutnya adalah ketersediaan pakan buatan (Cholik, 1999). Selama ini budi daya kepiting masih menggunakan benih yang ditangkap dari alam serta diberi pakan berupa ikan rucah. Kepiting bakau dapat makan berbagai macam ikan rucah, juga dalam bentuk moist pellet (Sulaeman \& Hanafi, 1992). Dari analisis kebiasaan makannya, diketahui bahwa kepiting bakau merupakan hewan pemakan segala yang terdiri atas $35,7 \%$ detritus, $23,6 \%$ ikan, dan $18,37 \%$ krustasea (Prasad \& Neelakantan, 1988a). Pada pengamatan pendahuluan

\footnotetext{
-) Peneliti pada Balai Besar Riset Perikanan Budidaya Laut, Gondol
} 
di laboratorium diketahui bahwa kepiting bakau juga dapat makan pakan buatan berupa pelet kering dengan baik, seperti juga dilaporkan Chin et al. (1992). Namun demikian sampai saat ini belum tersedia pakan buatan secara komersial untuk kepiting bakau.

Dalam pengembangan pakan buatan diperlukan tersedianya informasi kebutuhan nutrien pakan seperti protein, lemak, vitamin, dan lain-lain untuk kepiting bakau. Protein merupakan komponen utama untuk pertumbuhan, sehingga protein selalu mendapat perhatian utama dalam penyusunan formula pakan untuk hewan budi daya. Sementara itu data kebutuhan protein untuk kepiting bakau belum tersedia. Penelitian ini bertujuan untuk mengetahui kebutuhan protein bagi pertumbuhan kepiting bakau.

\section{BAHAN DAN METODE}

Yuwana (crablet) kepiting bakau diproduksi di hatcheri dengan menggunakan bak oval volume $5 \mathrm{~m}^{3}$. Sebanyak 180 ekor crablet dengan bobot awal ratarata $0,35 \pm 0,08 \mathrm{~g}$ dan lebar karapas rata-rata 1,36 \pm
$0,09 \mathrm{~cm}$ dipelihara secara individu dalam wadah supernet yang ditempatkan dalam bak volume $100 \mathrm{~L}$, dilengkapi dengan sistem air mengalir dan aerasi. Pada setiap bak percobaan dipelihara 5 ekor crablet. Percobaan dirancang menggunakan rancangan acak lengkap dengan 6 periakuan beda kandungan protein dalam pakan dan setiap perlakuan terdiri atas 3 ulangan.

Pakan percobaan dengan kandungan protein berbeda, yaitu $25 \%, 30 \%, 35 \%, 40 \%, 45 \%$, dan $50 \%$ dibuat dalam bentuk pelet dan dikeringkan dengan pengering dingin (freeze dryer). Sebagai sumber protein digunakan tepung ikan, tepung kepala udang, tepung hati cumi, tepung kedelai, dan kasein. Kandungan energi pakan dibuat sama dengan penambahan karbohidrat dari dekstrin. Komposisi pakan disajikan pada Tabel 1

Pakan diberikan 2 kali setiap hari dengan jumlah disesuaikan dengan respon makan kepiting. Jumlah pakan yang diberikan dicatat setiap hari. Setiap minggu dilakukan penimbangan kepiting secara

Tabel 1. Komposisi pakan percobaan (\% bahan kering)

Table 1. Composition of the experimental diets (\% dry matter)

\begin{tabular}{|c|c|c|c|c|c|c|}
\hline \multirow{2}{*}{$\begin{array}{l}\text { Bahan } \\
\text { ingredients }\end{array}$} & \multicolumn{6}{|c|}{ Pakan Percobaan (Experimental diets) } \\
\hline & CP-25 & CP-30 & $\mathrm{CP}-35$ & $C P-40$ & CP -45 & CP.50 \\
\hline Tp. ikan (Fish meal) & 20.8 & 28.3 & 35.9 & 39.4 & 42.8 & 46 \\
\hline Tp. kepala udang (Shrimp head meal) & 10 & 10 & 10 & 10 & 10 & 10 \\
\hline Tp. hati cumi (Squid liver meal) & 5 & 5 & 5 & 5 & 5 & 5 \\
\hline Tp. kedelai (Soybean meal) & 10 & 10 & 10 & 10 & 10 & 10 \\
\hline Kasein (Casein) & - & - & - & 3 & 6 & 9 \\
\hline Tp. terigu (Wheat flour) & 5.5 & 5.5 & 5.5 & 5.5 & 5.5 & 5.5 \\
\hline Minyak kedelai (Soybean oil) & 2.5 & 2.5 & 2.5 & 2.5 & 2.5 & 2.5 \\
\hline Minyak ikan (Fish oil) & 3.4 & 2.7 & 1.9 & 1.6 & 1.2 & 0.9 \\
\hline Lecithin (Lecithin) & 2 & 2 & 2 & 2 & 2 & 2 \\
\hline Mineral Mix ${ }^{* 1}$ & 3 & 3 & 3 & 3 & 3 & 3 \\
\hline Vitamin $\mathrm{Mix}^{\star 2}$ & 2.5 & 2.5 & 2.5 & 2.5 & 2.5 & 2.5 \\
\hline C M C (Binder) & 2 & 2 & 2 & 2 & 2 & 2 \\
\hline Dekstrin (Dextrin) & 34.2 & 26.7 & 19.1 & 12.6 & 6.2 & 1.6 \\
\hline Total & 100 & 100 & 100 & 100 & 100 & 100 \\
\hline
\end{tabular}

Komposisi nutrien (Nutrient composition; \% D.M.)

\begin{tabular}{lrrrrrr}
\hline Protein (Protein) & 26 & 31.4 & 37.4 & 41.8 & 46.8 & 51 \\
Lemak (Lipid) & 11.5 & 12.7 & 11.2 & 12 & 11.2 & 11.2 \\
Abu (Ash) & 11.3 & 10.9 & 11.2 & 12.4 & 12.5 & 12.7 \\
Serat (Fiber) & 3.9 & 3.9 & 4.2 & 4.4 & 4.7 & 4.9 \\
\hline
\end{tabular}

${ }^{* 1}$ Mineral mix (g/100 g diet): $\mathrm{K}_{2} \mathrm{HPO}_{4} 0.70 ; \mathrm{Ca}_{3}\left(\mathrm{PO}_{4}\right)_{2} 0.95 ; \mathrm{MgSO}_{4} .7 \mathrm{H}_{2} \mathrm{O} 1.07 ; \mathrm{NaH}_{2} \mathrm{PO}_{4} .2 \mathrm{H}_{2} \mathrm{O} 0.28$

*2 Vitamin Mix (mg/100 g diet): $p$-Aminobenzoic acid 15.80; biotin 0.63; inositol 632.00; Ca-pantothenate 94.80; niacin 63.20; pyridoxine- $\mathrm{HCl}$ 18.96; riboflavin 12.64; thiamin- $\mathrm{HCl} 6.32$; menadion 6.34; b-carotene 15.17; a-tocoferol 31.60; calciferol 1.90; cyanocobalamin 0.13; folic acid 1.26; choline-HCl 948.00 
individu untuk mengetahui pertumbuhannya. Untuk mengetahui pengaruh pakan percobaan, data pertumbuhan, sintasan, efisiensi pakan, dan kandungan protein serta lemak tubuh kepiting setelah percobaan dianalisis dengan ANOVA serta Uji Tukey (Steel \& Torrie, 1960). Untuk mendapatkan kebutuhan protein optimal digunakan analisis broken line (Zietoun et al., 1976).

\section{HASIL DAN BAHASAN}

Pertambahan bobot kepiting bakau selama 6 minggu percobaan menunjukkan bahwa kepiting bakau yang diberi pakan uji tumbuh dengan baik dan laju pertumbuhannya meningkat dengan meningkatnya kandungan protein pakan (Gambar 1). Demikian juga bakau (Scylla paramamosain) dapat makan dan memanfaatkan pakan buatan dengan baik. Chin et al. (1992) melaporkan bahwa kepiting bakau Scylla serrata juga dapat memanfaatkan pakan buatan untuk menunjang pertumbuhannya dengan baik. Informasi ini mendukung pengembangan pakan buatan untuk menunjang pengembangan budi daya kepiting bakau.

Kandungan protein pakan berpengaruh nyata $(P<0,05)$ terhadap bobot akhir, persen pertambahan bobot, lebar karapas, dan efisiensi pakan yuwana kepiting bakau (Tabel 2 dan Tabel 3). Bobot dan pertambahan bobot kepiting meningkat dengan meningkatnya kandungan protein pakan sampai pada level protein $45 \%$. Namun peningkatan kandungan protein pakan dari $45 \%$ menjadi $50 \%$ tidak

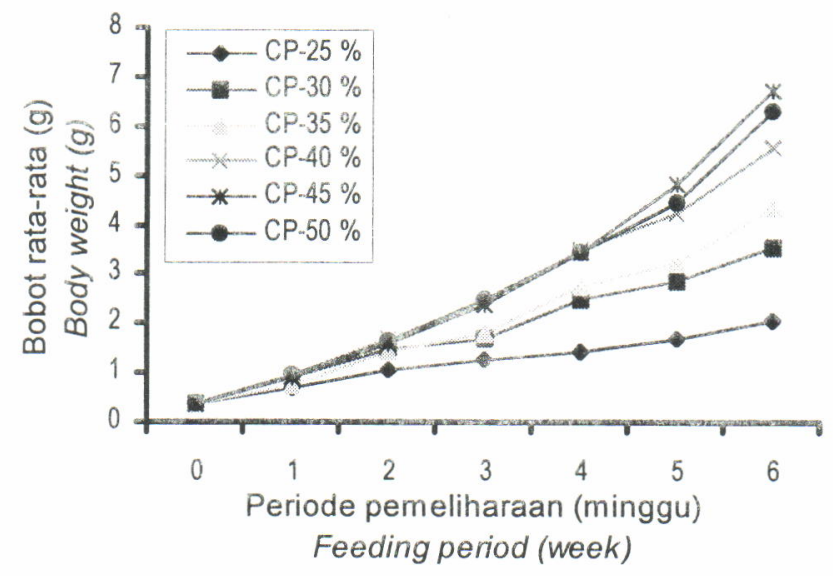

Gambar 1. Pertambahan bobot kepiting bakau (Scylla paramamosain) yang diberi pakan percobaan selama 6 minggu

Figure1. Weight gain of mud crab (Scylla paramamosain) fed experimental diet for six weeks

dengan pertambahan lebar karapas seperti terlihat meningkatkan bobot dan pertambahan bobot kepiting. pada Gambar 2. Hal ini menunjukkan bahwa kepiting Data ini menunjukkan kandungan protein pakan $45 \%$

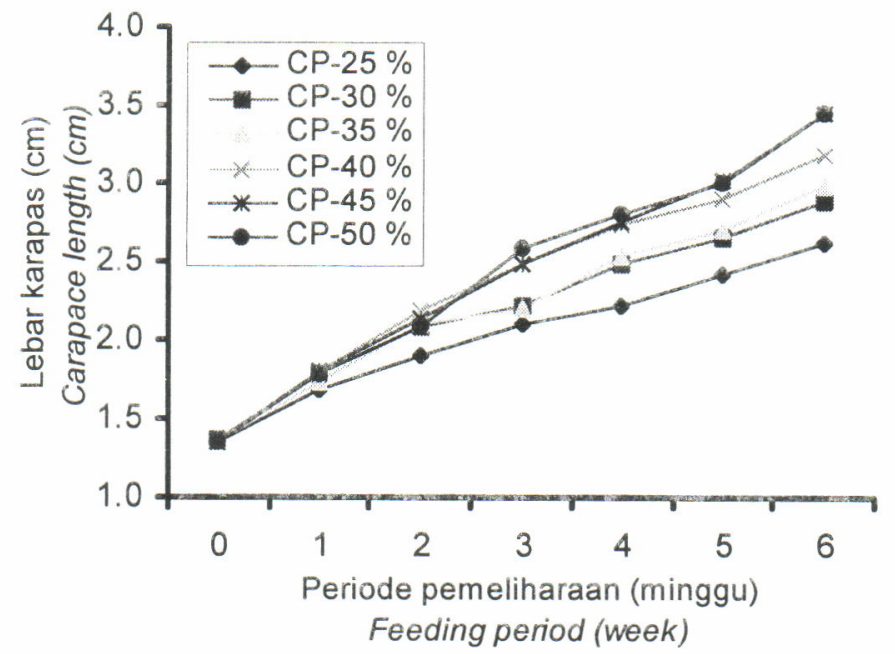

Gambar 2. Pertambahan lebar karapas kepiting bakau (Scylla paramamosain) yang diberi pakan percobaan selama 6 minggu

Figure 2. Carapace length of mud crab (Scylla paramamosain) fed experimental diet for six weeks 
memberikan pertumbuhan tertinggi untuk yuwana kepiting bakau. Chin et al. (1992) melaporkan bahwa kandungan protein pakan $35 \%$ dan $40 \%$ tidak memberikan pertumbuhan yang berbeda pada kepiting Scylla serrata. Lebih lanjut dilaporkan bahwa kepiting yang diberi pakan daging kerang menghasilkan pertumbuhan yang lebih baik. Namun pada penelitian ini Chin et al. (1992) hanya mencoba dua level protein pakan buatan, yaitu $35 \%$ dan $40 \%$, dan membandingkannya dengan pakan berupa daging kerang, yang jelas mempunyai kandungan protein lebih tinggi mencapai 61,34\% (Trino et al., 1999).

Kepiting Scylla serrata dan Scylla transquebarica yang diberi pakan daging kerang menghasilkan pertumbuhan lebih baik dibandingkan dengan yang diberi pakan pelet udang basah atau pelet udang kering maupun cumi. Sementara kepiting Scylla serrata yang diberi pakan ikan rucah pertumbuhannya tidak berbeda nyata dengan yang diberi pakan daging kerang (Marasigan, 1999). Pada percobaan dengan Scylla paramamosain juga tidak ditemukan pertumbuhan yang berbeda nyata antara kepiting yang diberi pakan dengan kandungan $35 \%$ dan $40 \%$ protein (Tabel 2). Berdasarkan broken line analysis
$35 \%-50 \%$ dan bervariasi menurut ukuran udangnya (Chen, 1993). Kebutuhan protein optimum untuk pertumbuhan udang penaeid dilaporkan berkisar antara $23 \%-57 \%$, yang juga bervariasi menurut spesies dan ukurannya (Kanazawa, 1993). Pada Tabel 2 juga terlihat bahwa peningkatan pertambahan bobot kepiting memperlihatkan kecenderungan yang sama dengan peningkatan lebar karapas. Ini menunjukkan adanya korelasi positif antara bobot dengan lebar karapas kepiting.

Sintasan kepiting tidak dipengaruhi oleh kandungan protein pakan $(P>0,05)$. Sebagian mortalitas dikarenakan kepiting keluar dari wadah dengan merusak sekat supernet. Konsumsi pakan per individu yang dihitung berdasarkan pakan yang diberikan menunjukkan penurunan dengan meningkatnya kandungan protein pakan. Walaupun pakan yang diberikan mempunyai kandungan energi yang sama, namun data konsumsi pakan memperlihatkan adanya fenomena pemenuhan energi, khususnya energi yang berasal dari protein pakan. Kepiting akan berhenti makan saat kebutuhan energinya terpenuhi. Efisiensi pakan yang menunjukkan proporsi pakan yang dapat dimanfaatkan untuk pertumbuhan, meningkat dengan

Tabel2. Pertambahan bobot, lebar karapas, sintasan, dan konsumsi pakan yuwana kepiting bakau yang diberi pakan dengan kandungan protein berbeda

Table 2. Weight gain, carapace width, survival, and feed consumption of mud crab juvenile fed experimental diets $^{\star 1}$

\begin{tabular}{|c|c|c|c|c|c|}
\hline $\begin{array}{c}\text { Pakan } \\
\text { percobaan } \\
\text { Experimental } \\
\text { diet }\end{array}$ & $\begin{array}{c}\text { Bobot akhir } \\
\text { rata-rata } \\
\text { Final weight }(g)\end{array}$ & $\begin{array}{c}\text { Pertambahan } \\
\text { bobot } \\
\text { Weight gain (\%) }\end{array}$ & $\begin{array}{c}\text { Pertambahan } \\
\text { bobot } \\
\text { Carapace } \\
\text { width }(\mathrm{cm})\end{array}$ & $\begin{array}{c}\text { Sintasan } \\
\text { Survival } \\
\text { (\%) }\end{array}$ & $\begin{array}{c}\text { Pakan yang } \\
\text { diberikan } \\
\text { Feed intake } \\
\text { (g/ind.) }\end{array}$ \\
\hline$C P-25$ & $2.08 \pm 0.30^{a}$ & $510.7 \pm 50.9^{a}$ & $2.62 \pm 0.06^{a}$ & 93.3 & $10.74 \pm 0.07^{a}$ \\
\hline CP-30 & $3.04 \pm 0.18^{\mathrm{ab}}$ & $875.1 \pm 84.2^{b}$ & $2.89 \pm 0.04^{b}$ & 86.7 & $10.58 \pm 0.92^{a b}$ \\
\hline CP-35 & $4.32 \pm 0.75^{b c}$ & $1187.5 \pm 106.0^{b}$ & $2.98 \pm 0.18^{b c}$ & 100 & $10.25 \pm 0.17^{a b}$ \\
\hline $\mathrm{CP}-40$ & $5.76 \pm 0.82^{c}$ & $1342.8 \pm 105.4^{b}$ & $3.19 \pm 0.14^{c}$ & 93.3 & $9.30 \pm 0.71^{a b}$ \\
\hline$C P=45$ & $7.05 \pm 1.16^{d}$ & $1942.6 \pm 146.0^{c}$ & $3.45 \pm 0.07^{d}$ & 93.3 & $9.69 \pm 0.40^{a b}$ \\
\hline$C P-50$ & $6.59 \pm 1.22^{d}$ & $1804.3 \pm 184.1^{c}$ & $3.45 \pm 0.23^{d}$ & 100 & $8.87 \pm 0.58^{b}$ \\
\hline
\end{tabular}

* Bobot awal (Initial weight): $0.35 \pm 0.08 \mathrm{~g}$; Lebar karapas awal (initial carapace width): $1.36 \pm 0.09 \mathrm{~cm}$. Nilai pada kolom dengan huruf yang sama tidak berbeda nyata (Values in the column with the same letter are not significantly different $(P>0,05)$

terhadap data persen pertambahan bobot kepiting diperoleh bahwa kebutuhan protein optimum untuk menghasilkan pertumbuhan maksimum yuwana kepiting bakau adalah $47,6 \%$.

Kebutuhan protein kepiting ini mendekati kebutuhan protein untuk udang yang juga termasuk kelompok krustase. Kebutuhan protein untuk pertumbuhan udang windu dilaporkan berkisar antara meningkatnya kandungan protein pakan sampai pada level $40 \%$. Sementara itu peningkatan level protein pakan dari $40 \%$ menjadi $45 \%$ dan $50 \%$ menghasilkan efisiensi pakan yang tidak berbeda nyata $(P=0,05)$ seperti terlihat pada Tabel 3. Hasil ini menunjukkan pakan dengan kandungan protein $40 \%=45 \%$ memberikan efisiensi pakan tertinggi untuk yuwana kepiting bakau 
Analisis komposisi tubuh kepiting menunjukkan bahwa kandungan protein pakan berpengaruh nyata $(\mathrm{P}<0,05)$ terhadap kandungan protein dan lemak tubuh kepiting bakau (Tabel 3). Kandungan protein tubuh kepiting meningkat dengan meningkatnya kandungan protein pakan sampai pada level $45 \%$. Sebaliknya kandungan lemak tubuh kepiting menurun dengan meningkatnya kandungan protein pakan. Protein

\section{KESIMPULAN}

1. Meningkatnya kandungan protein pakan, meningkatkan pertumbuhan dan kandungan protein tubuh yuwana kepiting bakau;

2. Kebutuhan protein optimum untuk menghasilkan pertumbuhan maksimum yuwana kepiting bakau adalah $47,6 \%$.

Tabel 3. Komposisi proksimat tubuh kepiting dan efisiensi pakan (FE) yuwana kepiting bakau yang diberi pakan dengan kandungan protein berbeda

Table 3. Proximate composition of whole body and feed efficiency (FE) of juvenile mud crab fed experimental diets

\begin{tabular}{cccccc}
$\begin{array}{c}\text { Pakan } \\
\text { percobaan } \\
\text { Experimental diet }\end{array}$ & $\begin{array}{c}\text { Protein } \\
\text { Protein (\%) }\end{array}$ & $\begin{array}{c}\text { Lemak } \\
\text { Lipid (\%) }\end{array}$ & $\begin{array}{c}\text { Abu } \\
\text { Ash (\%) }\end{array}$ & $\begin{array}{c}\text { Serat } \\
\text { Fiber (\%) }\end{array}$ & FE \\
\hline CP-25 & $33.3 \pm 0.2^{\mathrm{a}}$ & $5.8 \pm 0.2^{\mathrm{ab}}$ & $43.5 \pm 0.0$ & $7.5 \pm 0.3$ & $0.18 \pm 0.01^{\mathrm{a}}$ \\
CP-30 & $34.3 \pm 1.1^{\mathrm{ab}}$ & $6.8 \pm 0.4^{\mathrm{a}}$ & $41.4 \pm 2.1$ & $7.3 \pm 0.8$ & $0.30 \pm 0.02^{\mathrm{b}}$ \\
CP-35 & $34.8 \pm 0.6^{\mathrm{ab}}$ & $6.8 \pm 0.9^{\mathrm{a}}$ & $42.9 \pm 1.8$ & $7.4 \pm 0.7$ & $0.36 \pm 0.03^{\mathrm{b}}$ \\
CP-40 & $36.0 \pm 1.3^{\mathrm{bc}}$ & $5.3 \pm 0.3^{\mathrm{b}}$ & $43.4 \pm 0.7$ & $7.4 \pm 0.9$ & $0.52 \pm 0.05^{\mathrm{c}}$ \\
CP-45 & $37.2 \pm 1.6^{\mathrm{c}}$ & $5.4 \pm 0.3^{\mathrm{b}}$ & $42.3 \pm 2.6$ & $7.8 \pm 0.6$ & $0.52 \pm 0.03^{\mathrm{c}}$ \\
CP-50 & $36.9 \pm 0.5^{\mathrm{c}}$ & $4.8 \pm 0.3^{\mathrm{b}}$ & $41.2 \pm 2.2$ & $7.7 \pm 0.7$ & $0.40 \pm 0.06^{\mathrm{c}}$ \\
\hline
\end{tabular}

Nilai pada kolom dengan huruf yang sama tidak berbeda nyata $(P>0,05)$

Values in the column with the same letter are not significantly different $(P>0.05)$

dimanfaatkan sebagai sumber energi dan untuk pertumbuhan. Kelebihan protein disimpan dalam tubuh sebagai jaringan. Kepiting yang diberi pakan dengan kandungan protein tinggi (40\%-50\%) dapat menyimpan lebih banyak proteinnya di dalam tubuh, yang ditunjukkan dengan meningkatnya kandungan protein tubuh. Prasad \& Neelakantan (1988b) melaporkan komposisi biokimia daging kepiting bakau Scylla serrata bervariasi menurut ukurannya. Kepiting ukuran kecil dengan lebar karapas $51-80 \mathrm{~mm}$ mempunyai kandungan protein lebih tinggi dengan kandungan lemak relatif lebih rendah. Pada kepiting dengan ukuran lebih besar dan yang dewasa dengan lebar karapas 81-130 mm ditemukan kandungan proteinnya tetap konstan, sedangkan kandungan lemak dan glikogennya mengalami penurunan. Siddiquie et al. (1987) juga melaporkan, bahwa dari 85\%-95\% bahan kering daging kepiting Scylla serrata, $55 \%-65 \%$ adalah protein. Sementara kandungan karbohidrat dan lemaknya adalah rendah. Hasil yang sama juga dilaporkan George \& Gopakumar (1987) dimana daging kepiting Scylla serrata mengandung cukup tinggi protein dengan lemak dan karbohidrat yang rendah. Kadar abu kepiting relatif tinggi, yaitu mencapai $41,2 \%-43,5 \%$ untuk semua perlakuan. Kadar abu ini sebagian besar diduga berasal dari bagian cangkang kepiting.

\section{DAFTAR PUSTAKA}

Chen, H.Y. 1993. Recent advances in nutrition of Penaeus monodon. World Aquaculture Society. 24: 231-240.

Chin, H.C., Gunasekera, U.P.D., and Amandakoon, H.P. 1992. Formulation of artificial feed for mud crab culture: A preliminary biochemical, physical and biological evaluation. In Angell, C.A. (ed.). Report of the Seminar on the Mud Crab Culture and Trade. Surat Thani, Thailand. p. 179--184.

Cholik, F. 1999. Review of mud crab culture research in Indonesia. In Keenan, C.P. and Blackshaw, A. (eds.). Mud Crab Aquaculture and Biology. ACIAR Proceeding No. 78. Canberra. p.14 - 20

Direktorat Jenderal Perikanan. 1999. Statistik Perikanan Indonesia. Departemen Pertanian, Jakarta. 61 pp.

George, C. and K. Gopakumar. 1987. Biochemical studies on crab Scylla serrata. Fish. Technol. Soc. 24: 57. -61 .

Kanazawa, A. 1993. Prawn nutrition. In Hock, C.S. and Saidin, T.H. (eds.). New Technology in Aquaculture. Malaysian Fisheries Society, Occasional Publication No. 6. p. 9- 98 .

Marasigan, E.T. 1999. Development of practical diet for grow-out of mud crab species Scylla serrata and Scylla tranquebarica. In Keenan, C.P. and Blackshaw, A. (eds). Mud Crab Aquaculture and Biology. ACIAR Proceeding No. 78. Canberra. p.187--195. 
Prasad, P.N. and Neelakantan, B. 1988a. Food and feeding of mud crab Scylla serrata (Decapoda: Portunidae) from Karwar waters. Indian J. Fish. 35: 164--170.

Prasad, P.N. and Neelakantan, B. 1988b. Chemical composition of the edible crab, Scylla serrata. Beverage Food World. 15: 37--38.

Siddiquie, P.J.A., Akbar, Z. and Qasim, R. 1987. Biochemical composition and calorific values of the three edible species of portunid crabs from Karachi. Pak. J. Sci. Ind. Res. 30: 119--121.

Sulaeman dan Hanafi, A. 1992. Pengaruh pemotongan tangkai mata terhadap kematangan gonad dan pertumbuhan kepiting bakau (Scylla serrata). Jurnal Penelitian Budidaya Pantai. 8: 55--62.

Steel, R.G.B. and Torrie, J.H. 1960. Principles and Procedures of Statistics. McGraw-Hill, New York. 481 pp.

Trino, A.T., O.M. Millamena, and C.P. Keenan. 1999. Monosex culture of mud crab (Scylla serrata) at three stocking densities with Gracilaria as crab shelter. In Keenan, C.P. and Blackshaw, A. (eds.). Mud Crab Aquaculture and Biology. ACIAR Proceeding No. 78. Canberra. p. 61--66.

Zietoun, I.H., Ullrey, D.E., Magee, W.R., Gill, J.L. and Bergen, W.G. 1976. Quantifying nutrient requirements of fish. J. Fish. Res. Board Ca. 33: 167--172. 